\title{
PENDIDIKAN DAN PERUBAHAN SOSIAL DI MANGKUNEGARAN SURAKARTA 1912-1940
}

\author{
Guntur Arie Wibowo *
}

\begin{abstract}
Abstrak
Sekolah Siswo Mangkunegaran merupakan bagian dari Politik Etis yang pada awalnya bertujuan mempersiapkan pegawai pangreh praja, memperoleh tenaga administrasi yang murah dan terdidik dari lingkungannya sendiri. Dari Sekolah Siswo lahir tenaga-tenaga terdidik yang pada akhirnya mengisi profesi baru pada perusahaan gula Tasikmadu maupun Colomadu milik Mangkunegaran. Perusahaan gula Mangkunegaran dan perkebunan-perkebunan di sekitar Surakarta membutuhkan banyak tenaga kerja administrasi. Pemerintah swapraja Mangkunegaran tidak mungkin mendatangkan dari Barat karena biaya yang mahal.

Adanya profesi-profesi baru dari kalangan terdidik, maka muncul para pekerja baru yang berstatus priyayi. Golongan ini datang dari lingkungan priyayi, tetapi mereka seringkali bergerak keluar dari lingkungan pangreh praja atau dengan kata lain keluar dari lingkungan tradisional. Mereka hidup dalam perbatasan antara masyarakat pribumi dan masyarakat kolonial. Betapapun tidak ada garis pemisah sosial yang absolut antara priyayi baru dan priyayi lama, antara kaum intelektual dan pejabat-pejabat pribumi, akan tetapi banyak orang dari kalangan bawah yang karena profesinya menjadikan mereka priyayi baru. Mereka dihormati seperti kaum priyayi tradisional. Banyak diantara mereka menyesuaikan diri dengan gaya hidup priyayi lama.
\end{abstract}

\section{Kata kunci : Pendidikan, Perubahan Sosial}

\section{Pendahuluan}

Salah satu bagian yang cukup penting dari kebijaksanaan Politik Etis adalah bidang pendidikan. Kebijaksanaan dalam bidang pendidikan bukan hanya suatu bagian dari politik kolonial, melain- kan merupakan inti politik kolonial. Politik Etis membawa per-kembangan pendidikan yang cukup pesat di seluruh wilayah Hindia Belanda, termasuk Surakarta.

Pelaksanaan Politik Etis memang banyak penyelewengan namun demikian bukan berarti tidak ber-

"Guntur Arie Wibowo adalah Dosen Pendidikan Sejarah IKIP PGRI Madiun Jl. Setiabudi 85 Madiun. 
dampak positif. Politik Etis telah mendorong perubahan sosial di kalangan penduduk pribumi. Hal itu disebabkan banyak penduduk Bumiputera yang kemudian mengenyam pendidikan Barat sebagai suatu cara untuk merubah pemikiran. Pendidikan dianggap sebagai alat penyeleksi dan latihan seseorang untuk memperoleh jabatan dalam masyarakat, seperti halnya di Jawa yang merupakan pusat kekuasaan kolonial. Sistem pendidikan di Jawa menunjukkan bahwa pendidikan menjadi kriteria yang lazim untuk pengangkatan pegawai pada berbagai dinas, baik pada lembaga pemerintah maupun pada perusahaan-perusahaan individual.

Pendidikan Barat saat itu menjadi idaman banyak orang. Masyarakat lebih menghargai mereka yang mempunyai latar belakang pendidikan Barat tanpa memperhatikan asal usulnya, akan tetapi dengan keadaan ini bukan berarti setiap orang memperoleh kesempatan yang sama untuk mendapatkan pendidikan Barat. Pendidikan Barat hanya tersedia bagi golongan Eropa, golongan yang dipersamakan dengan orang-orang Eropa dan Barat serta anak priyayi tinggi saja.

Di Surakarta terdapat bermacammacam sekolah model Barat. Menurut data yang dikeluarkan oleh lembaga pendidikan di wilayah Surakarta tahun 1930, secara garis besar beberapa jenis sekolah itu antara lain: (a) Sekolah-sekolah negeri berbahasa daerah, (b) sekolah-sekolah neutral berbahasa Belanda, (c) sekolahsekolah yang dikelola oleh Zending, missi, Muhammadiyah, Budi Utomo, dan dikelola pemerintah kerajaan Copgave Van Openbare Onderwijsriehtingen in Het Gewest Soerakarta, 1931).

Salah satu sekolah yang berdiri di Surakarta saat itu adalah Sekolah Siswo di Praja Mangkunegaran pada 1912. Sekolah ini merupakan bagian penting dari sistem pendidikan modern di zaman kolonial. Lahirnya kebijakan politik etis mendorong perluasan pendidikan model Barat yang menggantikan sistem pendidikan tradisional yang dikenal sebelumnya. Pengembangan pendidikan Barat sesungguhnya masih diskriminatif dan ambivalen karena bias kepentingan kolonial. Sekolah Siswo semula hanya bertujuan mencetak tenaga terdidik yang murah untuk kepentingan perusahaan gula. Meski demikian, berdirinya Sekolah Siswo telah memperluas terbentuknya kelas terpelajar pribumi yang akan menjadi agen penting dalam perubahan masyarakat menuju kebebasan dan kemerdekaan.

Berdasarkan deskripsi di atas, maka menarik untuk dikajii perkembangan pendidikan di Mangkunegaran dimulai dari munculnya Sekolah Siswo untuk pertama kalinya di Mangkunegaran hingga berlanjut sampai dengan munculnya sekolah HIS atau HIS Siswo atau HIS Mangkunegaransche School.

\section{Perkembangan Pendidikan di Mangkunegaran}

Perkembangan pendidikan di Mangkunegaran tidak banyak meng- 
alami hambatan dari pemerintah Belanda, meskipun kebijaksanaan Mangkunegaran dalam bidang pendidikan termasuk pelaksanaannya di lapangan tidak terlepas dari pengawasan pemerintah Belanda. Seperti halnya Kasunanan, maka untuk mendapatkan tenaga administratif yang sesuai dengan kehendak kerajaan, Mangkunegaran juga mendirikan sekolah-sekolah yang diperuntukkan bagi para abdi dalem dan sentono dalem.

Mangkunegaran VI adalah seorang penguasa yang peduli akan pendidikan rakyatnya. Semula ia kurang tertarik pada pendidikan model Barat, tetapi mengingat kebutuhan rakyatnya akan pendidikan jenis ini, maka ia mulai berusaha untuk mendirikan sekolah model Barat. Perhatian Mangkunegaran VI terhadap pendidikan diwujudkan dengan mendirikan sekolah model Barat dan pendirian dana belajar yang disebut dengan Studiefonds. Sekolah yang pertama kali didirikan adalah Sekolah Siswo. Sekolah ini pada tahun 1912 dijadikan sekolah No. 1 atau Angka Siji yang diperuntukkan bagi anakanak kaum kerabat, putra-putra bangsawan, para pegawai Mangkunegaran dan para perwira legiun (Konsep Berita Oesaha dan Djasa S.P.J Mangkunegaran VII terhadap Pendidikan dan Pengadjaran, 2004). Mengenai Sekolah siswo ini akan dibahas lebih lanjut dalam sub bab berikutnya. Selain Sekolah siswo yang kebanyakan muridnya laki-laki, Mangkunegaran juga mendirikan sekolah untuk para gadis dengan nama Sisworini, didirikan tahun 1912 yang mengambil tempat di halaman Istana atau Tjapuri.

Studiefonds atau dana belajar yang didirikan Mangkunegaran VI pada tahun 1912 ini bertujuan memberikan bantuan, berupa pinjaman uang untuk menyelesaikan pendidikan. Dengan cara ini diharapkan para putera keluarga raja, pegawai praja dan perwira legiun dimungkinkan untuk melanjutkan sekolahnya. Dari awal berdirinya, studiesfonds sudah melaksanakan tugasnya, meskipun pada saat itu belum ada peraturan yang mendasari cara kerjanya. Baru pada tahun 1913 cara kerjanya didasarkan pada peraturan sementara tertanggal 15 Oktober 1913, No. 11/Q. Empat tahun kemudian peraturan sementara tersebut diundangkan dalam Rijksblaad atau Pranatan Pustaka Praja Mangkunegaran tahun 1917 No. 20 yang sifatnya sudah permanen (Rijksblaad Mangkoenagaran no. 20, tahun 1917).

Berdasarkan pranata tersebut, beasiswa yang dikeluarkan dari dana belajar terdiri dari dua kelompok. Kelompok A merupakan beasiswa untuk umum dan kelompok B beasiswa khusus untuk putra sentono, opsir legiun, dan para nara praja. Beasiswa yang diterima siswa tersebut bukan diberikan secara cuma-cuma, tetapi mereka harus mengembalikan dengan cara mengangsur setelah mereka lulus dan memperoleh pekerjaan. Pendirian Studieponds ini memberikan manfaat bagi para siswa di Mangkunegaran. Selain meningkatkan kualitas sumber daya manusia di wilayahnya, juga 
menambah jumlah siswa yang menempuh pendidikan menengah dan tinggi baik di dalam maupun di luar negeri (Nederlands).

Setelah Mangkunegaran VI turun tahta, penggantinya yaitu Mangkunegara VII adalah seorang yang sangat memperhatikan pendidikan di wilayahnya. Sekolah yang telah dirintis oleh pendahulunya dilanjutkan dan bahkan diadakan pendirian sekolah-sekolah yang lain. Pada masa pemerintahan Mangkunegaran VII inilah pendidikan di Mangkunegaran mengalami perkembangan pesat.

Sekolah Sisworini mengalami beberapa perubahan. Pada awalnya sekolah ini biasa disebut dengan nama Pawulangan Bocah Wadon Ing Mangkunegaran (pendidikan untuk anak gadis di Mangkunegaran). Sekolah ini merupakan sekolah pagi yang memberikan pelajaran ke rumahtanggaan, seperti memasak, mengurus keuangan rumah tangga, kesehatan, menjahit, selain itu juga memberikan pelajaran membaca, menulis, berhitung. Pelajaran agama tidak pernah diberikan di sekolah ini. Lama pendidikan tujuh tahun dan diajar oleh guru-guru berkebangsaan Eropa dan pribumi yang dianggap mampu mengajar. Sekolah ini diperuntukkan bagi anak-anak sentono dalem dan abdi dalem Mangkunegaran, namun jika dimungkinkan masih ada tempat. Sekolah ini tidak berkeberatan untuk menerima siswa di luar golongan itu, selama siswa tersebut memenuhi persyaratan yang diajukan, yaitu tidak menderita penyakit menular dan mereka sudah diimunisasi cacar
(Rijksblaad Mangkunegaran no. 33, tahun 1917).

Pada tahun 1923 sekolah ini ditutup dan dibuka kembali tahun 1924 yang berganti nama menjadi Huishoud Cursus Sisworini atau kursus kerumahtanggaan

(Rijksblaad Mangkunegaran no. 6, tahun 1924). Pada tanggal 1 Agustus 1938 mengalami perubahan lagi menjadi Huishoudschool Sisworini, yaitu sekolah pagi yang dihubungkan dengan Van Deventer School. Dalam perkembangannya sekolah ini berada dibawah pengamatan Van Deventer School dan dalam waktu tertentu murid-murid Van Deventer School boleh mengajar pada sekolahan tersebut. Untuk rencana pelajarannya ditetapkan menurut sekolah kerajinan/ketrampilan (Lagere Nijverheidschool Goepermen), lama pendidikannya tiga tahun (Makloemat Huishoudschool - Sisworini). Pada tahun 1942 diambil alih oleh pemerintah Dai Nipon dan digabungkan dengan sekolah Kepandaian Putri milik pemerintah Jepang (Bendel tentang Sekolah Sisworini-Kartiwismo Mangkunegaran).

Di Mangkunegaran terdapat sekolah Van Deventer yang didirikan tahun 1927 yang merupakan sekolah menengah putri milik swasta. Sekolah ini baru bisa berdiri setelah mendapat bantuan keuangan dari praja Mangkunegaran. Pelajaran yang diberikan sama seperti pada sekolah Sisworini, hanya saja ada tambahan pelajaran menyanyi, menari dan karawitan. Kurikulum yang lengkap menjadikan sekolah ini sebagai pusat pendidikan wanita pada saat itu dan dianggap sebagai tempat persiapan 
bagi seorang wanita sebelum terjun ke masyarakat.

Sekolah Van Deventer memang memiliki kualitas yang lebih jika dibandingkan dengan sekolah Sisworini milik Mangkunegaran. Selain kurikulumnya yang lengkap, sekolah ini juga mendapat perhatian khusus dari Mangkunegaran VII. Fasilitas-fasilitas yang diberikan kepada sekolah Van Deventer antara lain murid-murid di sekolah ini diperkenankan menggunakan Pendopo Agung Mangkunegaran dengan gamelannya untuk pelajaran menari, menyanyi dan karawitan sekali dalam seminggu. Dalam kegiatan in,i seringkali Gusti Kanjeng Ratu Timur (Permaisuri Mangkunegara VII) secara langsung memberikan contoh pelajaran pada murid-murid.

Empat kali dalam seminggu, murid-murid Van Deventer juga diperkenankan menggunakan kolam renang, lapangan tenis dan lapangan olah raga lainnya di dalam istana Mangkunegaran. Untuk membentuk watak ke-Timur-an bagi wanita yang telah mendapatkan pengetahuan Barat ini, diberikan juga pelajaran mengenai etiket dan adat Jawa agar mereka tidak terasing di lingkungannya sendiri. Fasilitas-fasilitas istimewa tersebut menyebabkan sekolah ini sangat terkenal dan banyak diminati oleh para gadis dari berbagai daerah seperti Jawa Timur dan Jawa Barat, tidak terkecuali dari Surakarta sendiri. Bahkan, putri kedua dan ketiga Mangkunegaran VII juga menjadi murid di sekolah ini.

Perhatian Mangkunegaran VII dalam pendidikan juga diwujudkan dalam pendirian ruang baca untuk umum dan perpustakaan pada tahun 1920 yang bertempat di depan gedung pertemuan Mangkunegaran. Tujuannya agar para pemuda di Mangkunegaran mempunyai pengetahuan yang lebih luas dan dapat mengikuti perkembangan peristiwa yang terjadi disekitarnya. Mengingat kemampuan para Nara Praja di Mangkunegaran dalam berbahasa Belanda umumnya belum baik, maka pada tahun 1924 pihak Mangkunegaran memerintahkan semua pegawai pembantu juru tulis dan yang diatasnya serta perwira legiun untuk mengikuti kursus bahasa Belanda dan tambahan pengetahuan umum. Hal tersebut bertepatan dengan diadakannya cabang Nederlandsch leergang di Solo, bahkan dalam kesempatan tersebut Mangkunegara VII membantu memberi tempat dan sekaligus menjadi ketuanya (Tg. Yosowidagdo, 1989: 66).

Di Mangkunegara juga diselenggarakan kursus bahasa Jawa bagi abdi dalem. Tujuannya agar dapat berbahasa Jawa yang benar, menulis dengan benar sesuai dengan ejaan umum yang diajarkan di sekolah. Kursus tersebut memberikan penjelasan mengenai arti kata-kata, penggunaan kata-kata dalam kalimat, mengajarkan peraturan tentang surat menyurat dalam bahasa Jawa dengan huruf latin menurut ejaan umum. Kursus dilaksanakan tiap hari senin, selasa, rabu dan kamis. Waktunya pagi hari dari jam 9 sampai jam 10, sengaja diberikan satu jam saja agar mereka dapat kembali bekerja sesuai dengan tugasnya. Pengajar dalam 
kursus ini adalah seorang abdi dalem senior yang cukup pengetahuannya.

Mangkunegaran mempunyai dua pabrik gula, yaitu Tasikmadu dan Colomadu. Untuk mendapatkan tenaga teknik yang disesuaikan dengan kebutuhan kerajaan, maka mulai tahun 1929 didirikan sekolahsekolah teknik kayu dan besi di sekitar pabrik gula tersebut. Sekolahsekolah itu tidak hanya diperuntukkan bagi calon tenaga kerja di kedua pabrik milik Mangkunegaran, tetapi juga memberi kesempatan bagi pemuda-pemuda yang ingin menjadi tukang yang berpengajaran.

Selain mendirikan sekolahsekolah untuk kalangan putra sentana, anak-anak perwira legiun dan para nara praja yang merupakan sekolah bagi kalangan elit, Mangkunegaran juga mendirikan sekolah untuk rakyat kebanyakan atau Sekolah Desa. Penyelenggaraan Sekolah Desa ini sepenuhnya ditanggung oleh Praja Mangkunegaran, mengingat kemampuan rakyatnya yang merasa kesulitan untuk membiayai putra putrinya untuk sekolah. Pendirian Sekolah Desa atau Volksschool di wilayah Mangkunegaran ini mulai dilaksanakan pada tahun 1918 dengan jumlah 19 buah. Pada tahun 1927 jumlahnya menjadi 53 dan dalam tahun 1930 jumlahnya meningkat menjadi empat kali lipat dari permulaan tahun 1918, yaitu menjadi 79 sekolahan. Satu tahun kemudian bertambah menjadi 81 sekolahan, 30 sekolahan berada di kota Mangkunegaran dan 51 sekolahan berada di Wonogiri. Dengan demikian selama
Mangkunegara VII berkuasa, terdapat 81 Sekolah Desa. Jumlah murid juga mengalami peningkatan yang cukup berarti, pada tahun 1918 terdapat 1162 siswa, namun pada tahun 1930 telah meningkat menjadi 6910 siswa (Wasino, t.t.).

Rencana pembangunan Sekolah Desa di wilayah Mangkunegaran terhambat setelah adanya krisis ekonomi yang melanda dunia pada tahun 1930. Krisis tersebut juga mempengaruhi perekonomian di Mangkunegaran, meskipun demikian Sekolah Desa di wilayah Mangkunegaran masih bisa bertambah. Pada tahun 1935, Sekolah Desa milik Praja Mangkunegaran meningkat menjadi 103 sekolahan, 81 sekolahan hasil usaha Mangkunegaran sendiri dan sisanya merupakan pelimpahan dari sekolahsekolah milik Gubernemen. Sekolah Desa tersebut sampai tahun 1939 belum mengalami penambahan, tetapi jumlah muridnya mengalami banyak peningkatan yaitu sekitar 13.000 siswa. Suatu jumlah yang tidak sedikit mengingat suasana dalam masa penjajahan.

Pada masa menjelang kemerdekaan Indonesia maupun sesudahnya atau sekitar tahun 1950 Sekolah Desa yang selanjutnya disebut Sekolah Rakyat masih mengalami penambahan. Di Kabupaten Kota terdapat 113 buah sekolah dan di Kabupaten Wonogiri terdapat 231 sekolah. Dengan demikian, bekas kerajaan Mangkunegaran pada masa setelah kemerdekaan telah meninggalkan Sekolah Rakyat sebanyak 344 sekolah. 
Perhatian Mangkunegaran VII tidak hanya terbatas pada pendidikan dasar saja. Pada tahun 1938 mengajukan permohonan kepada Direktur Pendidikan dan Kebudayaan di Batavia agar diperkenankan mendirikan MULO pribumi di wilayahnya. Alasannya agar ada sekolah yang menampung lulusan Volksschool dan vervolgschool dengan menggunakan biaya rendah, dan supaya Mangkunegaran mendapatkan tenaga administrasi yang sesuai dengan kriteria yang dibutuhkan. Berdasarkan permohonan di atas, maka mulai tanggal 1 Agustus 1938, dibukalah Inheemse Muloschool kursus empat tahun.

Selain menyelenggarakan pendidikan secara formal, Mangkunegaran juga mengadakan program pemberantasan buta huruf. Tujuannya adalah membekali masyarakat Mangkunegaran agar mempunyai kemampuan membaca dan menulis atau dengan kata lain membuat mereka menjadi melek huruf. Program pemberantasan buta huruf ini dilaksanakan oleh perkumpulan Krida Mudo (KM). Suatu perkumpulan yang didirikan oleh Mangkunegaran VII pada bulan November 1934 yang bertujuan memupuk semangat kedaerahan atau provinsialisme, yang berasaskan pada pengetahuan umum untuk menolong diri sendiri dengan melakukan berbagai kegiatan yang sekiranya dapat menambah penghasilan.

\section{Berdirinya Sekolah Siswo}

Praja Mangkunegaran mengusahakan pendirian sekolah model
Barat yang pertama yaitu sekolah Siswo pada tahun 1912. Sekolah siswo sebenarnya sudah ada sebelum tahun tersebut. Sebelumnya, sekolah siswo bernama Pamong Siswo atau Pawiyatan Siswo yang mempunyai arti pengajaran atau pendidikan bagi anak-anak. Disebutkan pula bahwa Mangkunegara VI pada tahun 1902 telah memasuki Pamong Siswo dan lulus pada tahun 1908 (Moch. Sidik Gondhowarsito, 2002: 46).

Sekolah dengan bahasa pengantar bahasa Jawa tersebut mengajarkan tata cara menurut adat Jawa asli. Pawiyatan Siswo terutama dimasuki oleh anak-anak Sentono yang merupakan kalangan elit. Didalamnya diajarkan etika hidup orang Jawa, sejarah terbentuknya Praja Mangkunegaran, dan manajemen modernisasi etika yang meliputi ajaran (piwulang) tentang tata krama, kesetiaan dan kecintaan terhadap praja. Penceritaan tentang sejarah Mangkunegaran terhadap para putra sentono telah menjadi kebiasaan di Mangkunegaran.

Dengan cara tersebut, mereka di perkenalkan dan diharuskan untuk memahami asal usul nenek moyangnya yang berasal dari satu keturunan, yaitu Raden Mas Said. Dari penceritaan tersebut diharapkan akan tumbuh rasa memiliki dan bertanggung jawab terhadap prajanya sesuai dengan falsafah Tridharma yaitu Melu Handarbeni, Melu Hangkrungkebi, Mulat Sariro Hangrasa Wani. Semboyan Tridharma dijadikan pegangan dalam memimpin pemerintahan di Praja Mangkunegaran, mulai dari Mangkunegara I hingga 
Mangkunegara VIII. Pamong Siswo lebih mementingkan bagaimana cara menanamkan dan mempertahankan adat ketimuran di dalam lingkup keraton. Nilai-nilai budaya Jawa yang harus dipegang teguh, tanpa mementingkan sisi intelektualnya.

Pamong Siswo hanya sebatas pada lingkup keluarga keraton saja dan jauh dari sistem pengajaran Barat. Pemikiran yang masih sangat sederhana tidak memungkinkan mereka untuk menerima budaya asing. Mereka takut terpengaruh budaya asing dan meninggalkan budaya aslinya yang akan mengakibatkan mereka terasing dalam lingkungannya sendiri.

Sebenarnya Sekolah Siswo ini dalam perkembangannya mengalami beberapa perubahan sistem pengajaran. Sesuai dengan peraturan yang dibuat oleh pemerintah Belanda bahwa Kepala Dinasti Mangkunegaran akan selalu berusaha memajukan pengajaran rendah bagi kaum Bumiputera di dalam wilayahnya, maka pemerintah Mangkunegaran selalu mengikuti petunjuk-petunjuk yang diberikan oleh pemerintah pusat. Masih dalam tahun 1912 Sekolah Siswo diubah menjadi Sekolah No. I atau Sekolah Angka I. Perubahan tersebut dirasakan terlambat mengingat surat keputusan pemerintah Belanda tanggal 28 September 1892 No. 44 (Lembaran Negara 1893 No.123), sekolah dasar atau sekolah rendah Bumiputera di Hindia Belanda dibagi menjadi dua kategori yaitu Sekolah Kelas I dan Sekolah II (Van der Wal, 1997: 5).
Sekolah kelas I atau Angka I adalah sekolah yang didirikan oleh pemerintah Belanda untuk pribumi yang ingin memperoleh pendidikan seperti di ELS. Oleh pemerintah, alumni sekolah ini tidak diarahkan ke sekolah yang lebih tinggi, sehingga mereka membatasi kurikulum yang diajarkan. Seorang lulusan Sekolah Kelas I hanya dapat menjadi pegawai rendahan (klein ambtenaar). Atau jika ingin melanjutkan sekolah, hanya bisa sekolah guru atau ke bagian persiapan OSVIA tetapi tidak ke OSVIA atau MULO. Sedangkan Sekolah Kelas II diperuntukkan bagi rakyat kebanyakan.

Sebagai Sekolah Angka I, sistem pengajaran pada Sekolah Siswo mengikuti asas-asas politik pengajaran yang pada umumnya dilaksanakan di daerah yang langsung diperintah oleh Gubernemen. Pengajaran di Praja Mangkunegaran akan diawasi oleh pihak Gubernemen dan biaya pengawasan itu akan ikut ditanggung oleh Mangkunegaran secara seimbang. Berdasarkan ketentuan sekolah Bumiputera Angka I, maka Sekolah Siswo merupakan sekolah rendah yang diperuntukkan bagi kalangan atas di Mangkunegaran, seperti anak Sentono atau keluarga raja, dan putra-putra pejabat kerajaan. Hal tersebut menunjukkan bahwa pembagian kelas dalam struktur masyarakat terlihat jelas. Melihat hak-hak yang diperoleh setiap anggota masyarakat, pembagian kelas tersebut bersifat tertutup dan tradisional. Sifat dasar ini mempengaruhi arah pembaharuan yang dilakukan dalam masyarakat, ter- 
masuk pembaharuan dalam bidang pendidikan.

Penerimaan murid di Sekolah Siswo dipengaruhi oleh tujuan sekolah. Sekolah-sekolah pertama di Jawa dimaksudkan untuk mendidik pegawai pemerintah, begitu juga dengan sekolah Mangkunegaran. Alasan tersebut menyebabkan Sekolah Siswo hanya menerima anak laki-laki sebagai murid. Adat istiadat pada waktu itu menentang pendidikan formal untuk kaum wanita, disamping masyarakat sendiri tidak melihat adanya manfaat bila kaum wanita dididik dengan cara yang sama seperti anak laki-laki. Wanita hanya dianggap berperan penting dalam rumah tangga. Untuk itu bagi kaum wanita di Mangkunegaran dibuatkan sekolah khusus yang memberikan pelajaran kerumahtanggaan.

Kurikulum pada Sekolah Siswo, seperti yang telah ditentukan dalam peraturan tahun 1893 terdiri atas pelajaran-pelajaran membaca, dan menulis dalam bahasa daerah dalam huruf daerah dan latin, membaca dan menulis dalam bahasa Melayu, Berhitung, Ilmu Bumi, Ilmu Alam, Sejarah, menggambar, dan ilmu ukur tanah. Pelajaran di kelas 1 sampai kelas 3 diberikan dalam bahasa setempat dengan tulisan daerah. Bahasa Melayu dimulai di kelas 4, sedangkan huruf latin diajarkan mulai kelas 2. Bagi Sekolah Siswo Angka Satu milik Mangkunegaran, pelajaran etika Jawa masih tetap yang terpenting. Ajaran adat ketimuran tetap tidak boleh dilupakan apalagi ditinggalkan, oleh karenanya, meskipun pendidikan model Barat telah diberikan tetapi tidak memberikan banyak perubahan pada siswanya.

\section{HIS Mangkunegaransche School}

Sekolah Siswo Kelas Satu atau Angka Satu memang diperuntukkan bagi kaum priyayi, akan tetapi tidak populer di kalangan priyayi, seperti umumnya sekolah Angka Satu di Hindia Belanda yang tetap sebagai sekolah terminal tanpa kesempatan melanjutkan pelajaran. Bahkan, sekolah ini tidak memberi latihan yang cukup untuk menempuh ujian pegawai rendah atau Klein Ambtenaars examen. Kalangan priyayi lebih memilih untuk memasukkan anak-anaknya ke ELS dibanding dengan Sekolah Angka Satu. ELS yang didirikan pada tahun 1818 ini pada mulanya merupakan satu-satunya jalur seseorang untuk dapat mengikuti Klein Ambtenaar examen dan satu-satunya lembaga bagi mereka yang menginginkan pendidikan lanjutan. Tidak mengherankan apabila para orang tua lebih suka memasukkan anaknya ke ELS.

Bertambah arus masuk anakanak Bumiputera ke ELS menimbulkan reaksi yang keras dari pihak orang-orang Belanda. Menanggapi hal tersebut,maka bahasa Belanda mulai dimasukkan ke dalam program Sekolah Kelas Satu atau Angka Satu dan lama studi diperpanjang dari 5 tahun menjadi enam tahun. Perubahan ini dijalankan secara berangsur-angsur karena langkanya guru-guru Belanda. Dalam perkembangan selanjutnya Sekolah 
Angka Satu berubah menjadi HIS atau Hollands Inlanders School.

HIS yang mulai didiriakan pada tahun 1914 merupakan penjelmaan dari Sekolah Angka Satu dengan masa pendidikan tujuh tahun. Dengan dibukanya HIS ini memberikan kemungkinan yang lebih besar bagi para murid untuk melanjutkan pendidikannya sekaligus sebagai persiapan untuk memasuki sistem pendidikan kolonial. Sekolah ini dibuka atas desakan masyarakat Bumiputera khususnya masyarakat golongan atas, karena sekolah sebelumnya ternyata tidak memenuhi syarat bagi murid-murid untuk melanjutkan pendidikan. Berdasarkan ketentuan dari pemerintah Belanda tersebut, maka Sekolah Siswo Angka Satu milik Mangkunegaran pun diubah menjadi HIS Siswo Mangkunegaransche School.

Dalam pelaksanaannya, HIS terutama dimaksudkan sebagai standartschool yaitu sekolah berdasarkan standar. Untuk menentukan status sosial seseorang yang berhak memasukkan anaknya ke HIS, pemerintah membuat ketentuan yang dituangkan ke dalam staatblaad 1914 no. 359. Ketentuan tersebut memuat empat dasar penilaian mengenai status sosial seseorang yaitu: keturunan, jabatan, kekayaan dan pendidikan. Di samping itu, pemerintah juga menggunakan penilaian berdasarkan pada penghasilan orang tua. Hasil penilaian ini dibagi dalam tigas kategori. Kategori A termasuk kaum bangsawan, pejabat tinggi dan swasta kaya yang berpenghasilan bersih lebih dari f. 75,perbulan. Kategori B ialah orang tua tamatan MULO dan Kweekschool ke atas. Untuk kategori C merupakan pegawai rendah, pengusaha kecil, militer, petani, nelayan dan orang tua yang pernah mendapat pendidikan HIS. Untuk orang tua yang termasuk kategori C ini dianggap sebagai golongan menengah ke bawah, sedangkan kategori A dan B dianggap sebagai kelas atas dan mendapatkan prioritas pertama dalam memasukkan anaknya ke HIS. Ketentuan tersebut menyebabkan golongan menengah ke bawah kurang mendapat kesempatan menikmati pendidikan model Barat tersebut. Padahal pendidikan jenis ini merupakan salah satu jalan bagi terjadinya suatu mobilitas sosial.

Ketentuan di atas tampaknya berlaku juga dalam wilayah Mangkunegaran. Sebagai contoh KRMH Saryono Suryosurarso, dapat masuk ke sekolah HIS Siswo Mangkunegaransche School, karena merupakan keponakan Mangkunegaran VII. Ayahnya KPH. Suryosurarso adalah adik kandung Mangkunegara VII. Oleh ayahnya, KRMH Saryono Suryosurarso dimasukkan ke HIS milik Mangkunegaran ini dengan bayaran tertinggi. Mengenai uang bayaran sekolah dapat dilihat dalam tabel berikut :

\section{Tabel 1}

Peraturan Uang Bayaran Sekolah Pada HIS Siswo Mangkunegaran 1930

\begin{tabular}{|c|c|c|c|c|}
\hline \multirow{2}{*}{$\begin{array}{c}\text { Pendapatan } \\
\text { orang tua }\end{array}$} & Anak I & Anak ke-II & Anak ke-III & $\begin{array}{c}\text { Anak } \\
\text { ke-IV }\end{array}$ \\
\cline { 2 - 5 } & & & \\
$0,-$ - f 50 & $1,-$ & 0,50 & 0,25 & 0,25 \\
\hline $50,-$ - f 100 & 1,50 & 0,75 & 0,50 & 0,25 \\
\hline $100,-$ - f 150 & $2,-$ & $1,-$ & 0,75 & 0,50 \\
\hline $150,-$ - f 200 & 2,50 & 1,50 & $1,-$ & 0,75 \\
\hline $200,-$ f 250 & & & & \\
\hline
\end{tabular}


Sumber : Arsip Mangkunegaran No B. 52.

Berdasarkan Tabel 1 di atas maka dapat diketahui bahwa hanya kalangan tertentu saja yang bisa menyekolahkan anaknya ke HIS Siswo Mangkunegaran. Sekolah ini menerima murid berdasarkan status sosialnya. Bayaran sekolah ditentukan berdasarkan pendapatan orang tua. Bagi orang tua yang mempunyai pendapatan tinggi, maka uang bayaran sekolahnya pun tinggi. Untuk anak kedua dan seterusnya, bayaran sekolahnya lebih rendah dari anak pertama yang nilainya ditentukan berdasarkan peraturan yang berlaku pada saat itu.

Sekolah dengan menggunakan bahasa Belanda sebagai bahasa pengantar merupakan sekolah yang sangat laku di Surakarta. Untuk itu, meskipun HIS Siswo merupakan sekolah yang mahal tetap saja banyak peminatnya. HIS Siswo yang menempati lokasi di Timuran (sekarang menjadi SMP 5) ini pada masa pemerintahan Mangkunegara VII (1916-1944) semakin maju. Mangkunegara VII adalah seorang penguasa yang sangat memperhatikan pendidikan rakyatnya, apalagi ia adalah lulusan Universitas Belanda dan berperan aktif dalam organisasi Budi Utomo. Melalui Barjawiyata yaitu Dinas Pengajaran Mangkunegaran, Mangkunegara VII melakukan perubahan dalam hal uang bayaran sekolah. Uang sekolah di HIS Siswo dibuat seringan-ringannya berdasarkan penghasilan orang tua.

Berdasarkan kebijaksanaan tersebut, setiap anak dapat mengikuti pendidikan di HIS Siswo. Setiap anak yang orang tuanya berpenghasilan tinggi, maka dikenakan bayaran tinggi, begitu juga sebaliknya. Bahkan ketika itu anak perempuan pun diperbolehkan untuk memasuki HIS Siswo, sehingga pada waktu itu HIS Siswo memiliki delapan kelas termasuk kelas 0 atau sejenis play group dengan masing-masing kelas diisi oleh 36 murid. Bukan jumlah yang sedikit mengingat pemikiran masyarakat ketika itu masih begitu sederhana.

Kurikulum yang digunakan di HIS Siswo menyesuaikan dengan kurikulum yang telah ditentukan oleh pemerintah Belanda sebagaimana tercantum dalam statuta 1914 no. 764, yang meliputi semua mata pelajaran ELS. Terdiri dari mata pelajaran menulis, membaca, berhitung, bahasa Belanda, Ilmu bumi dan mata pelajaran lain seperti Ilmu Alam, dasar-dasar bahasa Perancis, Bahasa Jerman, Sejarah Umum, Sejarah Dunia, Matematika, Pertanian, Menggambar, Pendidikan Jasmani, untuk pelajaran Bahasa Daerah dengan aksara latin dan melayu masih tetap diajarkan. Pelajaran kesusilaan dan adat ketimuran masih merupakan pelajaran yang penting di Sekolah Siswo.

Pelajaran bahasa Belanda merupakan pelajaran paling penting. Pelajaran ini meliputi $43,9 \%$ dari seluruh waktu pelajaran, selain itu waktu untuk mata pelajaran lain juga digunakan untuk menguasai bahasa ini. Dengan demikian waktu sesungguhnya untuk mempelajari bahasa Belanda menjadi 66,4\%. Pelajaran bahasa Belanda mendapat prioritas utama karena bahasa ini 
merupakan kunci untuk melanjutkan pendidikan, pintu dari segala kebudayaan Barat serta syarat untuk mendapatkan pekerjaan.

HIS Siswo mempunyai syarat khusus dalam hal penerimaan murid. Setiap anak yang akan masuk pada sekolah ini, minimal harus berumur enam tahun yang terlebih dulu harus masuk pada kelas 0 atau sejenis playgroup. Satu tahun berada di kelas 0 , kemudian baru diperkenankan masuk ke HIS selama tujuh tahun. Adapun guru-guru yang mengajar terdiri dari guru-guru yang berkebangsaan Eropa atau Pribumi yang telah lulus dari HKS (Hogere Kweekschool). Untuk jabatan kepala sekolah, mula-mula dijabat oleh orang Belanda yang mempunyai ijazah kepala Sekolah atau H.A atau Hoafdacte, tetapi lama-kelamaan orang Bumiputera pun dapat diangkat sebagai kepala sekolah. Sebagai contoh, tahun 1932 Mr. Sutopo Hadi Saputro adalah orang pribumi pertama yang menjabat sebagai kepala sekolah di HIS Siswo.

Sekolah milik Mangkunegaran ini semakin populer setelah adanya keputusan dari pemerintah Belanda, bahwa sejak tahun 1921, ijazah HIS telah disamakan dengan diploma pegawai rendah. Itu berarti bahwa mereka yang telah menyelesaikan pendidikan HIS dapat diterima dalam jabatan-jabatan pegawai rendah dalam dinas pemerintahan. Untuk menampung semakin meluapnya siswa yang berkeinginan untuk memasuki sekolah ini. Mangkunegara VII mengajukan izin kepada pemerintah Hindia Belanda untuk membangun HIS di Wonogiri. Akan tetapi HIS itu kemudian dibangun dan dikelola sendiri oleh pemerintah Kolonial Belanda.

Dalam sebuah pidatonya tahun 1931, Mangkunegara VII mengakui bahwa jumlah anak sekolah di wilayahnya memang meningkat, namun jumlahnya lebih kecil jika dibandingkan dengan Kabupaten di daerah Gubernemen yang terbanyak muridnya. Betapapun hasilnya, namun usaha pembangunan pendidikan atas inisiatif seorang bangsawan pribumi seperti Mangkunegara merupakan suatu prestasi yang cemerlang pada zamannya. Hal ini merupakan hal yang unik, karena di daerah-daerah lain, umumnya inisiatif pembangunan pendidikan berasal dari pemerintah kolonial Belanda.

\section{Penutup}

Munculnya Sekolah Siswo
merupakan angin segar bagi
masyarakat. Program pendidikan
Barat yang dicanangkan oleh pemerintah setempat dimaksudkan untuk mempertinggi taraf hidup masyarakat dengan harapan bahwa kenaikan taraf hidup tersebut akan memperbesar keuntungan secara pribadi maupun bagi pemerintah swapraja. Dampak pertama yang terlihat adalah munculnya penduduk yang terdidik, mengingat tujuan utamanya adalah menjadikan masyarakatnya melek huruf dan mencerdaskan.

Tujuan Sekolah Siswo pada awalnya adalah mempersiapkan seseorang untuk menjadi pegawai 
pangreh praja, memperoleh tenaga administrasi yang murah dan terdidik dari lingkungannya sendiri. Dari Sekolah Siswo tersebut memunculkan tenaga-tenaga terdidik yang pada akhirnya mengisi profesi baru pada perusahaan gula Tasikmadu maupun Colomadu milik Mangkunegaran. Perusahaan gula Mangkunegaran dan perkebunan-perkebunan di sekitar Surakarta membutuhkan kira-kira 870 orang tenaga kerja administrasi dan tenaga terdidik lainnya. Pemerintah swapraja Mangkunegaran sendiri tidak mungkin mendatangkan sejumlah tenaga kerja yang begitu besar dari Barat, mengingat pembiayaan yang mahal.

Adanya profesi-profesi baru yang harus diisi oleh tenaga terdidik ini membuka kesempatan munculnya para pekerja baru yang berstatus priyayi dalam masyarakat. Sekolah yang merupakan jalur untuk dapat mengantarkan seseorang pada profesi baru itu makin diminati masyarakat, dengan harapan dapat mencapai kedudukan yang mempunyai jenjang sosial tinggi dalam masyarakat. Pembaharuan pendidikan melalui Sekolah Siswo juga memunculkan suatu golongan terpelajar. Golongan ini biasanya datang dari lingkungan priyayi, tetapi mereka seringkali bergerak keluar dari lingkungan pangreh praja atau dengan kata lain keluar dari lingkungan tradisional. Mereka hidup dalam perbatasan antara masyarakat pribumi dan masyarakat kolonial.

Betapapun tidak ada garis pemisah sosial yang absolut antara priyayi baru dan priyayi lama, antara kaum intelektual dan pejabat-pejabat pribumi, akan tetapi banyak orang keturunan rendahan yang karena profesinya menjadikan mereka priyayi baru, yang menerima penghormatan sama seperti yang diperoleh kaum priyayi tradisional. Selanjutnya, banyak diantara mereka yang menyesuaikan diri dengan gaya hidup priyayi lama. Bagi masyarakat, hal tersebut tidak bisa dilepaskan dari peran Sekolah Siswo sebagai sekolah pengantar untuk mencapai kedudukan yang diinginkan.

Sekolah Siswo Mangkunegaran adalah bagian dari Politik Etis yang semula bertujuan untuk menghasilkan tenaga kerja yang akan dipekerjakan pada perusahaan dan tenaga administrasi pemerintah. Tujuan ini mendapat respon dari masyarakat setempat dan menganggap pendidikan adalah suatu kebutuhan. Pengaruh Kurikulum Barat yang diajarkan melalui sekolah tersebut kemudian membawa kesadaran baru pada penduduk akan keadaan mereka yang terjajah. Dari kesadaran tersebut memunculkan semangat nasionalisme dan memunculkan tokoh-tokoh dalam masyarakat yang berusaha mengubah kehidupan ke arah yang lebih baik. Beberapa tokoh kemudian mengarahkan perjuangan mereka pada pergerakan yang bertujuan untuk mencapai Indonesia merdeka. 


\section{Daftar Pustaka}

\section{Arsip}

Bendel Tentang Sekolah SisworiniKartiwismo.

Arsip

Mangkunegaran No. B 57.

Berkas Macam-Macam Pendidikan 1920-1941.

Arsip

Mangkunegaran No.B 108.

Rijksblad Mangkunegaran No. 20

Tahun 1917.

Rijksblad Mangkunegaran No. 33 Tahun 1917.

Rijksblad Mangkunegaran No. 6 Tahun 1924.

Makloemat Huishoud School-Sisworini 1938. Arsip Mangkunegaran No. P 2955.

\section{Buku}

Amin Singgih Tjitrosomo, R.T. 1941. Konsep Berita Oesaha Dan Djasa S.P.J. Mangkunegara Terhadap Pendidikan Dan Pengajaran. Surakarta: Reksopustoko.

Bauget, H Dan Brugmans, I.J. 1987. Politik Etis Dan Revolusi Kemerdekaan. Jakarta: Yayasan Obor Indonesia.

Sidik Gondhowarsito, Much. 2002. Mangkunegara VI 1996-1916 Pembaharu Pada Zamannya. Jakarta.

Wal, S.L. Van Der. 1997. Pendidikan Di Indonesia 1900-1940 (Buku II). Terj. Jakarta: Pendidikan Dan Kebudayaan.

Wasino. 1995. Politik Etis Dan Modernisasi Pendidikan Di Mangkunegaran 1900-1945. Laporan Penelitian Tidak Diterbitkan.
Yosowidagdo. 1989. Het Triwindhoe Gedenhoek Mangkunegoro VII. Terj. Surakarta: Reksopustoko.

\section{Internet}

books.google.co.id/books?isbn=979128 3117... 